\title{
British Immigration Policy, Depoliticisation and Brexit
}

Pinar Donmez and Alex Sutton

Published in Comparative European Politics (2020)

Accepted 17th January 2020

Word count: 11468 (without bibliography but including endnotes)

\begin{abstract}
This paper seeks to problematize the historical significance of the EU for British governing strategy with reference to immigration policy and the concept of depoliticisation. Situating British governing strategy in terms of the crisis-prone nature of capitalist society, this paper argues that British immigration policy has been depoliticised through, initially, the invocation of globalisation and, more recently, the EU. Through this strategy, the British state has been able to repeatedly claim that immigration policy is largely out of its hands, as they have no control over workers wishing to enter Britain looking for work. This paper makes three claims: firstly, immigration policy has been used as a means by both Conservative and Labour governments to manage inflation and labour; secondly, successive governments have sought to depoliticise immigration policy through reference to external forces; thirdly, this strategy of depoliticisation ultimately failed, politicising Britain's relationship with the EU and creating conditions for Britain's exit from the EU.
\end{abstract}

Keywords: Brexit Immigration Depoliticisation British politics Capitalism

\section{Introduction $^{1}$}

Over the past few years, as part of an increasingly pronounced trend in the aftermath of the 2008 global crisis, the issues of 'migrants' and migration have been brought onto the public and governmental agenda throughout Europe. In almost all cases, racist, nationalist and xenophobic discourses about migrants have been mobilized. These discourses have legitimised a set of corresponding policies as a solution to the so-called 'crisis' of migration and refugees. They have contributed to shifting blame and responsibility away from governments for the consequences of their austerity policies and preventing a progressive form of politicisation of substantive issues such as deepening social inequalities and insecurities, welfare and unemployment.

The goal of this paper is to contextualize the British EU referendum result in 2016 in terms of British immigration policy from a historical materialist perspective. We treat immigration policy as a key tool in the management of the British economy and, particularly, the availability of labour ${ }^{2}$. We argue that the consequences - both material and ideological - of British immigration policy were instrumental in politicizing Britain's membership of the EU. While there is now a burgeoning literature on the EU Referendum result (Moore and Ramsay, 2017; Gamble, 2018; Favell, 2019; Dorling and Tomlinson, 2019), which assesses the role of multiple underlying factors and potential ramifications, we are interested in specifically investigating the ways in which immigration has been brought onto centrestage of mainstream politics in this process (Dennison and Geddes, 2018). 
A historical materialist approach requires us to venture beyond the surface controversies of realpolitik in a particular national political setting (in this instance that of the UK) and investigate the underlying and potentially invisible yet global structural and social processes in a historical fashion (Probsting, 2015).

Therefore we seek to position British immigration policy within the historical development of three features of contemporary society: firstly, the development of employment and unemployment; secondly, the consolidation of the modern territorial state form; thirdly, the sundering of social life into separate political and economic spheres. This first section therefore provides the basis for understanding the modern phenomena of cross-border economic migration (Apostolova, 2016), the national political fallout from this process, and the capacity of the state to depoliticize these consequences ${ }^{3}$. The paper takes the view that depoliticisation derives from an attempt by governing authorities to insulate themselves from the political consequences of economic policies and conditions, which is itself made possible by an ideological conceit that justifies a crisis-prone and contradictory society.

Starting with this historical overview is crucial in three respects: Firstly, cross-border migration existed prior to capitalism and occurred with various motivations and objectives at varying scales but it should not be treated as a trans-historical phenomenon. We are particularly interested in the historically specific form of migration under capitalism. Secondly, delineating this historically specific form is crucial in order to provide a solid materialist foundation of the relationship between migration and capitalism and the constitutive role of labour as their common and interlinking dimension (Mezzadra and Nielsen, 2013; Apostolova, 2017). Lastly it enables us to position the contemporary developments such as Brexit and changing policies and perceptions towards migration within longer term historical trends in order to avoid exceptionalist assessments essentialising and reifying these developments as though solely belonging to the context of contemporary British politics (Benson and Lewis, 2019: 1-2, 5).

Scholars of depoliticisation have thus far largely focused on economic policy-making as the most common strategic tool in impressing this discipline on social relations. ${ }^{4}$ However, we argue that depoliticisation can also be enforced on other policy fronts by state managers. The main focus of this article is the uses and abuses of immigration policy as it is incorporated into overarching governing strategy. Migration could also be politicised in multiple diverse forms by social classes and political actors within and beyond the governing strategies of state managers. The space for such politicisation(s) may be opened up in relation to and as a consequence of depoliticized governing strategies themselves (Burnham, 2014; Donmez, 2014) or their eventual failure as observed in the British experience. Depending on the dynamics of class struggle, configuration of class forces and social movements, these forms can be reactionary, that is seemingly antineoliberal yet pro-capitalist, or progressive and anti-capitalist (Donmez, 2019). The focus on these politicisation(s) necessarily conceives migration, understood broadly as the movement of people across borders, to be integral to capitalist social relations and the territorial state form, as a contested political issue at the centre of class struggle. 
Therefore migration, in this framing, can be politicized or depoliticized as a subject of social and political contestation to either reify or expose and challenge the existing state of affairs. When migrants are targeted and blamed as the cause of all economic troubles in public debate and to justify further austerity policies that are implemented in tandem, their effect on broader social relations becomes depoliticizing despite the fact that migration attracts more and more public, media and governmental attention. In turn, we argue the actions, discourses and policies that produce these outcomes ultimately contribute to and enforce depoliticizing governing strategies. The analysis proposed in the following sections therefore is in line with a relational understanding of depoliticising and politicising forms of management as co-existing in governing strategies of capitalist states rather than following one another in strictly demarcated sequences (Burnham, 2017: 366).

The paper continues by offering a historical account of British political economy and the role immigration has played in British political life and economic policy. While the British state adopted a more open immigration policy in the years immediately following the Second World War, immigration became a highly politicised issue during a period of discretionary policy-making. This politicisation led to a stricter immigration policy, thereby diminishing the autonomy of state managers to act, thus contributing to the broader inability of governing authorities to address Britain's persistent economic problems. However, from the mid-1990s, British state managers deliberately operated an open immigration policy as part of a governing strategy that aimed to encourage competitiveness, productivity, and growth while containing inflation in the British economy. The political fallout from this policy, rather than being directed at the state, were initially depoliticised by New Labour's invocation of globalization and the logic of no alternative.

The paper then considers how New Labour's depoliticisation of immigration was not indefinitely sustained. With the Coalition government of 2010, this depoliticizing move changed form and the European Union increasingly became an external entity blamed for rising levels of immigration (Flinders and Buller, 2006). However, this too failed. The reactionary re-politicization of immigration was, we argue, one of the major factors in the calling and ultimate result of the referendum, facilitating the entrance of new nationalist actors into the mainstream political scene and substantially diminishing the government's autonomy to manage the British economy.

\section{Work in Capitalist Society}

Prior to capitalist society, the phenomenon of what is now termed unemployment was very different. The so-called 'labour market' was not constituted by workers seeking to sell their labour to the owners of the means of production. Rather, direct producers were tied, usually by birth, to landowners to whom they owed their livelihoods in all manner of productive activities and accordingly relinquished rent to their landlords in the form of labour, money, or goods (Dyer 2002:35; Brenner 1976:31; Postan 1975:82; Anderson 1974:44). Movement from one trade to another was extremely rare. Movement from one landlord to another was not a question of a worker's choice in a so-called labour market but, rather, workers were compelled to work for their lord (Hilton 1992:14; Sweezy 1992: 37-39). To mirror Marx's (1996 [1867]:179) characterization of 
the capitalist worker, the feudal worker was doubly unfree: labour was not a commodity she had in her power to sell and she was tied by necessity of subsistence and social ties to a particular overlord (see also Marx [1858] 1993:87; Anderson 1974:19-34; Burnham 2014:190-191).

In the European feudal system, therefore, unemployment still existed but not in the same form that we understand the term today. However, under capitalism unemployment becomes a constitutive part and predominant feature of social relations. A striking feature of capitalism is the separation of the worker from his means of subsistence, forcing the worker to seek employment (Denning 2010:80; Marx \& Engels 1975 [1844]:283; Marx 1996 [1867]:706). This is not a phenomenon that occurred solely in capitalism's infancy but is an ongoing and permanent feature of our society (Bonefeld 2011:380; Luxemburg 2003 [1913]:345-346; Mezzadra and Neilsen, 2013:36-7). Federici (2004:75) emphasizes the violent and repressive character of the process of workers' separation from the means of their production, thus qualifying the so-called 'emancipation' and 'liberation' of workers in the transition to capitalism:

'It was not the workers - male or female - who were liberated by land privatization.
What was "liberated" was capital as the land was now "free" to function as a means of
accumulation and exploitation, rather than as a means of subsistence. Liberated were
the landlords, who now could unload onto the workers most of the cost of their
reproduction, giving them access to some means of subsistence only when directly
employed.'

The transformation of human beings from serfs to workers was not simply a change of category for capitalist society. The owners of the means of production, while still expropriating the fruits of the worker's labour upon its purchase in the market, were now required to pay the worker a wage. With labour-power a commodity in the sphere of circulation, it now had a price that appeared to represent the value of worker's labour. Exploitation of and surplus value extraction from the worker was confined to the invisible sphere of production. Extending the working day and pushing the physical limits of the worker's capacity to work, and increasing the productivity of labour through investing in machinery, technology and reducing the contribution of living labour in production are the two strategies employed by capitalists to facilitate ever-expanding capital accumulation (Marx, 1996 [1867]: Parts 3-5). The two modes of surplus extraction also demonstrate the market's limits as these strategies culminate in the irresolvable tendency towards overaccumulation and overproduction (Clarke, 1994: 281-2). The imposition of market discipline upon both capital and labour is then undertaken by state managers (Clarke, 1988: 128, 131). These limits appear as a tendency to escape the rule of the market through competition between individual capitalists but also between workers (both in and out of work) in the quest for employment and, therefore, subsistence (ibid.).

'Capitalist production can by no means content itself with the quantity of disposable labour power which the natural increase of population yields. It requires for its free play 
an industrial reserve army independent of these natural limits...During times of crisis and stagnation, the industrial reserve army maintains the active labour army's gratitude for merely being in work: 'relative surplus population is therefore the pivot upon which the law of demand and supply of labour works'(Marx 1996 [1867]:629-633).

Capitalist society then rests upon the availability, flexibility and heterogeneity of workers, whose perpetually precarious position enables their exploitation, the extraction of surplus value and the growth of the capitalist economy. Therefore, we conceive the phenomenon of migration and migrant and refugee populations through the lens of Marx's conceptualization of the reserve army of labour and relative surplus populations (Apostolova, 2015; 2016; De Genova, 2016: 135-6; Rajaram, 2016; 2018; Merrill, 2011). Indeed, within Marx's account of capitalist accumulation is embedded a foundation for understanding labour migration taking into account the global nature of capitalist social relations and transcending a purely national approach (Miles 1956:78; Pradella \& Cillo 2015:147-148).

It is perhaps illustrative to consider Marx's (1988 [1870]:474-475) account of the role of Irish labour in England in the late-19 ${ }^{\text {th }}$ century:

'All industrial and commercial centres in England now have a working class divided into two hostile camps, English proletarians and Irish proletarians. The ordinary English worker hates the Irish worker as a competitor who forces down the standard of life. In relation to the Irish worker, he feels himself to be a member of the ruling nation and, therefore, makes himself a tool of his aristocrats and capitalists against Ireland, thus strengthening their domination over himself. He harbours religious, social and national prejudices against him.

This antagonism is kept artificially alive and intensified by the press, the pulpit, the comic papers, in short by all the means at the disposal of the ruling class.'

Marx here spells out the contours of the ideological structure that creates the fiction that immigration is a question of national division. Marx argues that apparent divisions between socalled native and non-native workers are fantastical, serving to manage class struggle exacerbated by the presence of non-native workers. However, one aspect of this situation that Marx does not explicitly flesh out is that this antagonism does not solve the problem of class struggle but merely channels it into another form.

Here we would like to emphasise that we do not build our argument around the claim that migration and migrant workers cause the suppression of wages for the resident workforce. This is a contested and controversial claim both in academic scholarship and the political mobilisation around migration (see, for example, Wilson, 2017; Financial Times, 2018; Portes, 2019). For us what is important here is to distil Marx's conceptualisation of 'industrial reserve army' and 'surplus population' within the framework he laid out while bearing in mind that wage is a form of appearance of value in capitalist society. This means, on the one hand, that the ideological 
construct of scapegoating migrants as the source of wage cuts should be challenged with the clear assertion that the culprit is capital accumulation. On the other hand, this approach challenges the efficacy of the mobilisation of workers' struggles solely around the surface appearance of wageform that diminishes the establishment of solidarity between resident and migrant workers.

Marx does not develop a comprehensive account of the management of labour-power and surplus populations - an absence commented upon by a number of scholars (Denning 2010:80; Lebowitz 2003:48-49; Harvey 1982:163; Merrill, 2011: 1548). This is the result, in large part, of Marx's limited systematic conceptualization of the state-form and its role within capitalist society. Particularly, Marx did not assess in depth the role of unpaid, invisibilised labour in its various forms and the continual expansion of the 'unpaid part of the working day' in the surplus value production and capital accumulation (Federici, 2004: 115; Dinerstein, 2002: 213) ${ }^{5}$. This process indeed went hand in hand with the expropriation of peasants from the commons in Europe and colonial expansion and expropriation outside Europe, deepening the gendered, racial, geographical inequalities, asymmetries, conflicts and alienation within the global working class (Federici, 2004: 68; Fanon, 2004 [1961]: 27, 57; Merrill, 2011; Boatca, 2015;Rajaram, 2018: 628).

From this viewpoint, primitive accumulation has been a universal process in every phase of capitalist development. Not accidentally, its original historical exemplar has sedimented strategies that, in different ways, have been re-launched in the face of every major capitalist crisis, serving to cheapen the cost of labor and to hide the exploitation of women and colonial subjects (Federici, 2004: 16-17)

Recent scholarship at the intersection of critical political economy, global labour history and migration studies emphasizes the presence of multiple forms of labour and its commodification beyond 'free waged' labour in light of contemporary processes of informalisation and precarisation (van der Linden, 2001; 2004; 2012: 64; Roth, 2010; Mezzadra and Neilsen, 2013: 85; Ferguson and McNally, 2015; LeBaron and Phillips, 2019). This process is increasingly called a process of 'global proletarianisation' marked by de-industrialisation and casualisation in the advanced capitalist centres, mass migration, mass poverty and the shadow economy as well as subsistence farming, remittances as a means of survival and livelihood in migrant sending countries and the emergence of a new industrial working class within the capitalist periphery with complex articulations of class, gender and race (Roth, 2010: 218-227; Bhambra, 2017: 227; De Haas, 2005, 2012; Le De et. al., 2015).

The so-called law of the self-regulating market by no means determines the aforementioned process. Rather, the state actively steps in to monitor and regulate the expansion and contraction of the relative surplus population within and across borders through a series of tools and techniques, one aspect of which is generally referred to as immigration policy (Apostolova, 2015; Mezzadra and Neilsen, 2012: 68-9). In this light the next section will consider the origins of the state, the institution tasked with managing the various contradictions that beset the capitalist 
mode of production. One of the key tasks in this regard is the management of the peculiar commodity of labour-power within and outside the borders of the state.

\section{The State and the Depoliticisation of Immigration Policy}

The long, contested and violent process of the transformation from feudal to capitalist society led to the formal territorialisation of the state itself: the creation and formalization of the state's specific borders and boundaries, within which the central government could lay claim to absolute sovereignty (Cantat, 2016: 13-4).

The state has historically conditioned national and territorial characteristics. The territorial nature of the capitalist state therefore creates conditions for the existence of cross-border migration in its contemporary form (Cole, 2016: 261-2). The territorial boundaries of the state have been justified according to a nationalist ideology, which historically developed a racist character, particularly among European states, also providing justification for imperial expansion (Fanon, 2004 [1961]: 5, 53; Benson and Lewis, 2019). The value of this ideological framework was to justify and sustain capitalist society and its transformation of the old feudal order.

The transformation of feudal society into capitalist society also necessitated the transformation of how this new society would be governed. Uniquely, capitalism distinguishes between political and economic aspects of society: the public and contestable realm of politics and a civic and apparently non-political realm of economy and private intercourse. Therefore the state is a product of the differentiated political and economic forms of social life, masquerading as capitalist society's political form. As such, the rest of society-consigned to an apolitical, civic realm - has lost its political character. However, this differentiation is mere appearance - it is a fantastical aspect of the nature of capitalist social relations. This reproduction of social relations in fetishized, fantastical form, Holloway and Picciotto (1991: 114) argue, is an essential part of perpetuating class domination. Our global society is often understood as an 'aggregation of compartmentalised units' whereas it is in fact 'a single system in which state power is allocated between territorial entities' (Picciotto, 1991: 217).

As such, the distinction between politics and economics is a consequence of - and also permits - the exploitative and crisis-prone nature of capitalist society. While the state-form of these social relations propagates the formal equality of citizens, it simultaneously hides the violence and exploitation that takes place in the economic sphere. However, the perennial and inherent crises of capitalism make it difficult to sustain this view in perpetuity. The state therefore develops strategies of depoliticisation - attempts to distance the political character of decisionmaking from their consequences - simply because it cannot solve the inherent problems of a contradictory society.

As noted in the introduction, the study of depoliticization in British politics has tended to focus on economic policymaking (Burnham 2001, Kettell 2004, Rogers 2009; 2012). This literature has considered a variety of cases, including the role of gender in appointing Mark Carney as Governor of the Bank of England (Clarke \& Roberts 2014), post-war strategies of imperialism (Sutton 2017), and credit control deregulation by the Heath government (Copley 2017). Moreover, 
there has been considerable work undertaken on the failures of depoliticization as a governing strategy (Kettell 2008; Warner 2019). Numerous authors have sought to typologise depoliticization using various formulae (Burnham 2014; Flinders \& Buller 2006; Wood \& Flinders 2014).

The generally accepted view, however, is that depoliticisation helps to insulate the governing authorities from being held accountable or taking responsibility for their actions, and also transforms a political - or potentially social - crisis into a question of mere technical management. Moreover, by confining policy within an apparently 'external' regime, a strategy of depoliticisation can appear to constrain the future direction of policy, thus conditioning the expectations and behavior of both capital and labour (Kettell 2004:26). However, nothing can be truly depoliticized - it can only appear to be. It is, as Burnham (2014:191) notes, 'an institutional illusion' and therefore comprehending the nature of the political form of capitalist society rests on being able to decipher its origins in the material basis of production (Marx 1971 [1859]:20).

Extant scholarship on strategies of depoliticization has not substantively engaged with the phenomenon of migration or policies of immigration. ${ }^{6}$ Moreover, as noted earlier in this paper, the politicization of migration has become a generally observable global phenomenon in recent years (Van der Brug et al. 2015). However, the relationship between depoliticization and immigration has heretofore been unexplored. While scholarship on British immigration policy has noted that the issue of immigration has come to and from the fore of domestic politics and largely investigated its impact on the latter in party political and public opinion terms (Messina, 2001; Geddes, 2014), it has not sought to understand this in terms of strategies of depoliticization embedded within the contradictions at the heart of the management of gendered, racialized and bordered capitalist social relations in distinct territorialities (Layton-Henry 1992; Hansen 2000; Geddes and Scholten, 2016; Goodwin \& Milazzo 2017).

The fundamental crisis-ridden feature of capital accumulation that leads to overaccumulation and overproduction requires regular interventions by state managers to impose market discipline on capital as well as labour in a number of policy areas. Against this background, we confine ourselves to the question of how the particular role of the territorially bounded stateform strives to regulate and discipline migration as well as migrant/refugee and resident populations in its attempt to manage the inherently conflict-ridden social relations through immigration policy in the UK context. A key component, Cantat (2016: 13-5) argues, is the production of political subjectivities that are deemed acceptable and illegitimate and imposition of binary categories of citizen/non-citizen, national/foreigner and inside/outside. It produces on the one hand the 'political refugee' and on the other hand the 'economic migrant' as undesirables (Apostolova, 2016). Apostolova (2016: 34) exposes the use of this discursive violence for capital accumulation and domination in material terms. Such a separation forces migrants reaching European shores to demonstrate which type they belong to - those escaping 'political' violence or 'economic' troubles (ibid.). This strategy, perpetuated by states themselves, reproduces the economic domain, market, as though it were free of violence and results in the introduction of separate policies for the two migrant groups as well as hostility in public discourse and opinion (Apostolova, 2014; 2016: 36, 47). 
Therefore the migrant surplus populations are positioned on the border of the economic/political distinction as they experience two forms of capitalist exploitation and violence simultaneously and on an everyday basis: economic violence in the sphere of production and the political violence of the state as they are often deprived of the formal equality of citizenship rights (see also Cole, 2016). As a result the migrants' encounter with capitalism has the potential to unapologetically expose the latter's often mystified exploitative class character.

This process is also coupled with the management of 'undesirable' populations within the borders of the states. As Rajaram (2016:5) notes with reference to the case of Hungary:

'The governing of migration is not separate from domestic political and social processes but rather an outcome of these. Declarations of states of exception are means by which a surplus population is outlined at the edges of the nation-state, and point to ongoing processes of cultivating surplus and unproductive populations at the core. There is, in other words, a dialectical relationship between the management of a supposedly troublesome internal population, like the Roma, and that of an externalized population of migrants and refugees. There is a ready slippage between those narratives that pillory migrants and those that attack troublesome domestic populations.'

In this respect, Mezzadra and Neilsen (2012:64) specifically refer to 'practices of border reinforcing' employed by the state as the key mechanism and tool by which these strategies are employed. However, they also point out that these practices are continuously challenged by 'practices of border crossing' and necessarily involve 'multifarious struggles and tensions' between the two (ibid.; see also Apostolova, 2016; Cantat, 2016; Silverman, 2012). The difficulty of the management of labour-power from the viewpoint of state managers and the potentials it opens up from the viewpoint of class/border struggles due to the unique character of this commodity as we have outlined in the previous section should be highlighted here. Mezzadra and Neilsen (2013: 2634) emphasise that the 'bearer of labor power can never be fully identified with the commodified form of that same labor power' and that it is a 'form of power that exceeds, and in a certain sense precedes, processes of discipline and control, dispossession and exploitation'.

In this contested landscape, we identify two contemporary techniques identified by Mezzadra and Neilsen (2013) in managing and controlling migration that we could assess under the 'depoliticisation-repoliticisation' framework. Firstly, and most commonly in the British case, the externalisation of the management of migration beyond the territorial borders of the nation-state. Such as involving third countries in border regimes in order to control mobility before it reaches the border of the state in question, or through visa regimes and deportation procedures with third countries, or even and especially the invocation of processes of globalization or regionalisation. Secondly, the highly technocratic points-based system in which states specify a set of criteria through which prospective migrants are selected in terms of their degree of suitability to enter a particular economic, political, territorial space, deciding firmly who 'deserves' to get in and who has 
to be left out (ibid.: 68-69). It is within this broad framework we shall position the British experience with Brexit and the (de)politicisation of immigration in the following section.

\section{Post-War Governing Strategy and Immigration (1945 - 1992)}

As Burnham (2001:127) notes, successive British governments have been 'unable to solve the fundamental problems that beset the British economy (the relative productivity problem, the decline of the staple industries, recurrent inflationary pressure, the 'boom and bust' cycle)'. It is against this backdrop that we wish to set the political economy of British immigration policy.

The British Nationality Act 1948 initially permitted large-scale immigration into Britain from anywhere in the British Empire and Commonwealth territories (British Nationality Act, 1948: Chapter 56, Part I and II). Given the needs of the British economy in the immediate post-war period, this was to increase the availability of labour in general to fill specific gaps in the labour market caused by the manifold effects of the Second World War and high levels of post-war emigration (Drewry et al 2004:201; Spencer 1996:32-33). ${ }^{7}$ Britain used its imperial position among Commonwealth countries to support these goals: migrants were often highly skilled professionals, the labour of whom the British state deprived poorer Commonwealth countries (Tomlinson 2003:220). Although the 1948 Act enabled British imperial subjects to work in the UK without a visa, it was never intended to enable large-scale inward migration. British state managers, both Labour and Conservative, were consistently hostile to so-called 'new' Commonwealth immigration and uneasy about the 1948 Act for racist reasons of their own and the electorate's own racist reaction (Hansen 2000:5; Miles 1986:74; James 2004:369-373). Indeed, Carter et. al. (1987:1) note that the Labour Government set up a Cabinet Committee in 1950 to identify means of limiting immigration of 'coloured people from the British colonial territories'.

As Shilliam (2018:92-4) notes, the growth of a non-white population in the UK had contributed substantially to growing racial tensions. ${ }^{8}$ By 1961 , a poll suggested that up to $73 \%$ of the British public favoured increased immigration controls for 'coloured colonial immigrants' (Small \& Solomos 2006:243 cited in Shilliam 2018:93). As a consequence of the political tension surrounding non-white immigration, the Conservative government passed the 1962 Commonwealth Immigrants Act. The Commonwealth Immigrants Act 1962 (Chapter 21, Part I and II) curtailed this movement of immigrants substantially by introducing new controls and work permits, removing the freedom by which - especially non-white - citizens of the Commonwealth or British Empire could move to or work in Britain. ${ }^{9}$ British state managers sought to restrict immigration due to highly racist popular attitudes to non-white migrants and fears for social cohesion (Spencer 1997:155). Imperial relationships had been used in this endeavor too, with British politicians applying pressure within the Commonwealth to discourage non-white migration in an attempt to circumvent the 1948 Act; however, this was not always successful (James 2004:369). Drawing on archival sources, Carter et. al. (1987:2) document these 'covert, and sometimes illegal, administrative measures' instituted by both Labour and Conservative governments as early as $1952^{10}$. Ultimately the 1962 Act sought to provide a clear legislative answer to the problem of an increasingly politicised immigration situation (Spencer 1996:38). ${ }^{11}$ 
While Harold Macmillan famously remarked in 1957 that controlling inflation was the problem of our time', inflation had in fact been kept relatively well controlled below $10 \%$ since the end of the War. Post-war net immigration to the UK had been in positive figures until the Commonwealth Immigrants Act in 1962, which had contributed to keeping inflation low (LaytonHenry 1992:67. One feature of this legislation was to distinguish formally between white and nonwhite Commonwealth citizens - something that the 1948 British Nationalities Act had failed to do - and permitted entry only to Commonwealth citizens who had received an employment voucher from the Ministry of Labour (Gordon 1985:15; Shilliam 2018:94). Nevertheless, by the end of the 1960s, inflation was creeping up and by the early-1970s had reached nearly $25 \%$. However, successive governments - both Conservative and Labour - were unwilling to relax immigration controls due to the highly politicised nature of immigration into Britain and, hence, the electoral unpopularity of this position (Spencer 1997:134).

The 1964 General Election saw immigration become a major electoral issue, with both parties taking a hardline on immigration. The subsequent Labour government introduced even tighter controls on immigration by substantially reducing the number of available employment vouchers and ending the availability of unskilled work vouchers completely (Gordon 1985:16). The 1968 Commonwealth Immigrants Act further limited non-white immigration by requiring a migrant to prove that they had one parent or grandparent who had been born in Britain (ibid.:95; Bhambra 2017:221; Spencer 1997:136). The Heath government passed the Immigration Act 1971 hoping to 'capitalise on the popularity of stricter immigration controls' (Spencer 1997:144). The Immigration Act 1971 legalised immigration detention and granted discretionary and exclusive powers to immigration officers and the secretary of state to give/refuse leave to enter and remain respectively (Silverman, 2012: 1138). 1973 saw Britain join the EEC, committing the British state to freedom of movement between member states. However, 'new' Commonwealth immigration remained a highly politicised issue with both Labour and Conservative parties eager to exploit the subject for electoral gain (ibid.:147). As such, as Somerville (2007:20) notes, the general direction of immigration policy was restrictive with Britain's membership of the EEC providing the 'major exception' to this general trend. ${ }^{12}$ As Bhambra (2017: 221) notes, through 1962, 1968 and 1971 Immigration Acts 'people who came as citizens were gradually turned into immigrants'.

Official British migration statistics, estimated from the International Passenger Survey by the Office for National Statistics (ONS) remain questionable in terms of accuracy. ${ }^{13}$ However, these official statistics record static net migration levels until the mid-1990s (Drewry et al. 2004:202) but show substantial increase from 1997 onwards due to an apparent increase in non-EU migration (ONS 2017; Vargas-Silva and Sumption, 2018: 4).

Historically, therefore, British post-war immigration policy sought to manage the unsolvable dilemma between social cohesion and sustaining economic growth by keeping a tighter grip on certain aspects of migration flows (non- EU migration, refugees and asylum seekers and irregular migrants) while inserting arm's length control over others (EU migration) (Miles 1986:56; Geddes, 2005: 729-737). In fulfilling this obligation, in this instance, in trying to provide an ample supply of labour for the needs of capitalist production, the nationalist ideology of the capitalist 
territorial state was challenged. This trend was visible in the legislation of 1948 Act and EEC membership in 1973 which introduced a certain degree of free movement of labour into territorial borders. However, in not providing that ample supply of labour - with successive governments seeking to benefit from exploiting that nationalist ideology for short-term electoral gains - one key tool for managing labour and sustaining accumulation was made unusable (Miles 1986:79). The examples of this tendency were visible in the rolling back of the more open immigration legislation highlighted in this section. British state managers, as Bulpitt (1996:225) notes, pursued governing strategies and employed 'supportive manipulative techniques to ensure, as far as possible, that they achieve their crude, subsistence-level objectives'. As such, governing autonomy on this issue was diminished. This is a view echoed by James (2004:370) in that the interests of Britain's colonies, and former colonies, were always subordinated to the short-term political goals of British state managers at any given time.

\section{Immigration, Globalisation and Depoliticisation (1992 - 2010)}

The foundation of immigration policy did not significantly change in the early-1990s but did shift its focus, a consequence of its increasing international significance (Harvey 1999:33; Layton-Henry 1992:235). While the 1971 Immigration Act remained the foundation for British policy, the focus of the Major government's immigration policy became asylum-seekers and how best to control their entry and integration into British territory. This was in part due to the increasing number of arrivals of asylum seekers in the 1980s (Silverman, 2012: 1138). The 1993 Asylum and Immigration Appeals Act created an accelerated asylum appeals procedure under detention by-passing UK's commitments to Geneva Convention regulations (ibid.).

One of the goals of New Labour's economic strategy was to transform the UK labour market into a highly flexible one that enabled increased employment during conditions of growth and high unemployment during periods of recession (Hay 2009:472). One of the key means of constructing this particular labour market was immigration policy. This policy was to encourage economic migration to Britain, while at the same time seeking to restrict successful asylum applications and undocumented migration and creating hierarchies between these migrant groups (Somerville 2007:3). As Silverman (2012: 1138) notes, New Labour had 'inherited a backlog of unresolved asylum applications' by the time it came to power. Over the course of a decade, Labour governments produced two White Papers on asylum policy (1998 and 2002) and passed five Immigration and Asylum Acts in 1999, 2002, 2004, 2006 and 2009 (ibid.: 1138-40; Home Office, 2019). Together they legislated and consolidated the detention practices of asylum seekers awaiting first decisions on their claims, removed welfare provisions for the families of failed asylum seekers and extended detention and policing powers of immigration and border officers (ibid.: 1139). As both Fekete (2001:24) and Squire (2005:52) note, New Labour's central policy of 'deterrence' towards asylum seekers was consonant with a resurgent racism in British society. The tightening of asylum policy went hand in hand with increased liberalization of immigration policy for select migrant groups. New Labour sought to have their cake and eat it: by loosening restrictions on migration to the UK for economic reasons, they could reap the economic benefits; 
meanwhile, tightening asylum policy allowed the government a rhetorical cover for electoral purposes, permitting them to claim they were tough on immigration. The main framing device for New Labour's presentation of the immigration issue was globalization, thus transforming policy choices into apparently necessary, externally-imposed realities deriving from the erosion of state power, market imperatives, and the desire for market credibility and the appearance of governing competence (Watson \& Hay 2002; Flinders and Buller, 2006; for the pragmatic adoption of restrictive EU policies on asylum and immigration by the UK governments via opt-ins, see Geddes, 2005: 732-7).

Barbara Roche, the Minister for Asylum and Immigration, outlined New Labour's approach to immigration to the Institute for Public Policy Research in September 2000. In this speech, Roche (2000) linked clearly changes to the global economy to the need for a more open immigration policy, arguing that 'our economy is part of a global system that is becoming ever more tightly integrated... and international migration is a central feature of this global system'. She continued by stating that skill shortages were now emerging in the British economy and that Britain was 'in competition for the brightest and best talents - the entrepreneurs, the scientists, the high technology specialists who make the global economy tick'. In May 2001, however, the Labour Party Manifesto pledged to evict 30,000 failed asylum seekers from the country by 2004 (Guardian 2001).

In 2001, a Home Office report (2001:vii-viii) stated that factors leading to immigration were a consequence of globalization and 'therefore not likely to reverse. Migration may therefore be on a secular upward trend. Indeed, over the medium to longer term, migration pressures will intensify across Europe as a whole as a result of demographic changes... There is considerable support for the view that migrants create new businesses and jobs and fill labour market gaps, improving productivity and reducing inflationary pressures'. This representation of increased migration as a consequence of globalization presents the considered policy choices made by the New Labour government as a necessary consequence of apparently external forces. As Piven (1995:108) observed, New Labour's presentation of globalization therefore becomes 'a political force helping to create the institutional realities it purportedly merely describes'.

Immigration, though, remained a highly politicized issue (Dustmann et al. 2010:2-3). According to Ipsos MORI public opinion surveys, key issues of public concern were National Health Service, education, common market and EU between 1997 and 2001 . However, defense, foreign affairs and terrorism as well as race relations and immigration demonstrated a secular upward trend from early 2000 s onwards, which illustrate the securitisation of the race and immigration issue under the shadow of $9 / 11$ and 7/7 attacks. Eventually, race relations/immigration became the most important issue for the respondents in 2006 and 2007 (Ipsos MORI, 2006; 2014). In a 2004 speech, Tony Blair, fearful of the growing politicization of immigration, reiterated the logic of no alternative to the Confederation of British Industry:

'In a world of global interdependence our policies on migration cannot be isolated from our policies on international development or EU enlargement... This should not 
become a party-political issue. That would do real damage to national cohesion. It is above all an issue to deal with, not exploit.'

The 2005 General Election saw the Conservatives' campaign on an immigration platform, with the Party even proposing to withdraw from the 1951 United Nations Convention on Refugees (Bale 2008:326). This was not an idea completely at odds with the political atmosphere. As Blair (2010:523) recalled, 'the Tories had one good issue to beat us with: immigration.' Blair portrays the issue as if this were only a question of undocumented migration; however, he does make a noteworthy remark about the impact of immigration: 'The truth is that immigration, unless properly controlled, can cause genuine tensions, put a strain on limited resources and provide a sense in the areas into which migrants come in large numbers that the community has lost control of its own future' (ibid.523-524). However, again, this is placed solely in terms of the question of asylum seekers and undocumented migration $^{14}$ while managed migration through the pointsbased system (PBS) increased under New Labour ensuring the continual filtering and entry of the so-called 'deserving', 'desirable' migrants into the UK in line with the skills needs of the economy (Geddes, 2005).

The opportunity presented by the enlargements of the EU in 2004 and 2007 was too good to miss. Jack Straw recalled of the 2004 enlargement and his role in lifting provisional restrictions on the accession countries, 'we thought that it would be good for Britain if these folk could come and work here' (Guardian 2013). While the final figures of A8 migration to Britain were higher than expected, the economic basis for lifting restrictions had been carefully considered by the Treasury. ${ }^{15}$ Wright (2010:165-166) points out that the Treasury was convinced - and had managed to convince the rest of government - that the supply of labour was shrinking and that this was likely to lead to increased inflation and erode growth. As such, eschewing transitional controls on the accession countries 'would allow the economy to further grow without wage inflation' (ibid.:165). The policy of New Labour, then, was to use immigration policy as a tool to manage the competitiveness of Britain within the global economy; however, the consequences of this were increasingly problematic in a political sense.

As demonstrated above, New Labour sought to depoliticise immigration using the logic of no alternative, invoking globalization and the technical language of the requirements of the economy (Flinders and Buller, 2006: 313). Along these lines, Migration Advisory Committee (MAC), an independent, non-statutory public body was established in 2007 and tasked with advising the government on migration and shortage occupation related issues. ${ }^{16}$ Moreover, there were also attempts to incorporate border-reinforcing practices as highlighted earlier (Mezzadra and Nielsen, 2012; 2013) through the rules-based management of immigration policy with the introduction of PBS in 2008, in an effort to remove the discretionary nature - and political character - of existing immigration policy. Gordon Brown (2010) again emphasized the market logic of globalisation in a key speech on immigration prior to the General Election - his third solely on the subject in three years: 
'By controlling immigration for a fairer Britain - by investing in the skills of our own workforce, we can ensure the flexibility for our businesses to secure the highly skilled migrants they need while continuing to maintain control of net inward migration. Or we can opt for an arbitrary and unworkable quota - and deny our businesses the skills they need, damaging our competitiveness and threatening the future of British businesses. This is the practical choice people must make'

However, this rhetoric was increasingly unsuccessful. Between 2003 and 2007, immigration had become one of the top three issues in British politics (Somerville 2007:1; Ipsos MORI, 2006). Between 2008 and 2013 the economy became the top issue of concern for the British public continuously and by a large margin in comparison with other rivalling issue areas (Ipsos MORI, 2014). Nevertheless it was accompanied consistently with immigration and unemployment as the second and third most important issues (ibid.; see also Balch and Balabanova, 2016). By 2010, immigration had become the key issue on which the Labour party was failing (Bale et al 2011:405; Dunleavy 2012:7). Indeed, it was a more serious failing of the Labour Party for the electorate than the state of the economy and was a major reason for voters choosing against the Labour Party in the 2010 General Election (Ford \& Somerville 2010:13). As Peter Mandelson (2010:536) recalled, 'Not only was immigration at the top of many voters' list of concerns, it spoke directly to their sense of fairness and unfairness'. Mandelson (ibid.:561) himself linked immigration to Labour's failure in the election: 'In our final years of office, when economic times were tough, too many voters thought that while they were working hard and paying their dues, the government was working for others: bankers, immigrants, benefit recipients, or those we were helping in far-off foreign conflicts.' Indeed, this was an aspect of Labour's governing strategy that the Conservative Party sought to exploit for electoral purposes in the run up to the 2010 General Election (Bale et al 2011:402). This Election saw the formation of the Coalition government and another shift in the presentation of the issue of immigration. Immigration was to become increasingly framed in terms of the state's powerlessness to control EU migration in an effort to displace the responsibility for the failures in economic management in the post-2008 crisis context ${ }^{17}$.

\section{Europe, Politicisation and Brexit (2010 - present)}

From 2007, the Conservative opposition's rhetoric on immigration became much tougher (Bale et al.2011:402; Partos \& Bale 2015:179). Moreover, during talks over the formation of the Coalition government, the Conservative Party treated immigration as a non-negotiable aspect of the Conservative manifesto (Bale et al 2011:406; Conservative Manifesto, 2010: 21). In other words, the rhetoric of being tough on immigration was not something on which the Conservative leadership was willing to compromise.

The effects of the Financial Crisis led the Bank of England to keep interest rates at a thenrecord low level of $0.5 \%$ from 2009 until 2016 in order to stimulate economic growth and to sustain confidence in the banking sector. An anticipated consequence of this low rate was increased inflation. As such, the new Coalition government remained committed to an open immigration 
policy and a flexible labour force. The Coalition government's stated aim following their election in 2010 was to reduce net migration to the 'tens of thousands'. However, net migration figures, which continued informing government policy and were a key public indicator of such despite accuracy problems, had not demonstrated the desired results after one year of being in office (ONS 2012). ${ }^{18}$

Given that the Coalition government continued a managed open immigration policy, two strategies were employed to distance the political consequences of this policy from the governing authorities. Firstly, the Coalition government sustained a tough rhetoric on immigration throughout its five years in office but especially early on. David Cameron (2011), in a 2011 speech, made a 'no ifs, no buts' commitment to lower immigration, stating 'I believe controlling immigration and bringing it down is of vital importance to the future of our country' and pledged to 'reduce net migration to the levels we saw in the 1980s and 1990s.' In a 2012 speech to the Policy Exchange, Theresa May (2012) declared 'After years of mass immigration, we now face the enormous task of building an integrated, cohesive society. Allowing more and more immigration would make that impossible'. In these speeches, both Cameron and May emphasise the importance of reducing non-EU migration.

In contrast to the 1992-2010 period where there were 48 individual policy and legislative changes affecting immigration policy, there have been 129 of such changes between 2010 and June 2019 (Home Office 2019). In substantive policy terms, the Coalition government introduced the 'hostile environment' policy in 2012 which purportedly set out to identify and reduce the number of immigrants 'with no right to remain' with the majority of these measures legislated in the Immigration Acts 2014 and later 2016 (Partos \& Bale 2015:173). Further efforts included driving vans around the country adorned with anti-immigration slogans, a commitment from then-Home Secretary Theresa May to withdraw from the European Convention on Human Rights, and David Cameron's attempt to make it more difficult for EU migrants to claim benefits in the UK. This latter attempt at curtailing so-called 'benefit tourism' became a key part of Cameron's attempt to renegotiate the terms of Britain's membership of the EU prior to the 2016 referendum. While the hostile environment institutionalised and normalised various policing and reporting practices of socalled 'illegal' migrants not only by the Home Office but also by the NHS, schools and universities, banks and landlords, they have gradually impacted on those with the right to remain in the UK (BBC 2013a; Guardian 2012) ${ }^{19}$ As a result of this set of policies, the Conservative Party's reputation for competence on immigration had diminished substantially by the 2015 General Election while the significance of immigration as an electoral issue had only risen (Partos \& Bale 2015:180).

Secondly, following criticism of the Government's efforts to reduce net migration figures, the blame for the government's apparent impotence to change immigration policy was laid firmly at the door of the EU, shifting the government's rhetoric away from non-EU migration to EU migration. The EU was a particularly useful entity in terms of its depoliticizing role for state management (Flinders and Buller, 2006). Its apparent externality - as an 'international' actor removed from the traditional role of the state - grants it a greater apolitical quality. British state managers were thus able to capitalize on this more distant - and hence more convincing - form of depoliticisation of immigration policy. As Burnham (2001:134) notes, 'the stronger (and more 
distant) the set of 'rules', the greater maneuverability the state will achieve, increasing the likelihood of attaining objectives'.

Linking immigration to the British state's membership of the EU had been a sustained part of both Coalition and Conservative governments' strategy following the failure of both governments to meet their pledges to reduce immigration figures (Roos 2018). This strategy became more pronounced in the run-up to the 2015 General Election as the issue of immigration became more pertinent to the electorate. As Partos \& Bale (2015:180) note, as the Conservative's rhetoric on immigration became tougher, the issue itself only became more pressing to the wider public (for the media coverage and salience of the issue before and during the EU Referendum see Allen, 2016; Moore and Ramsay, 2017). In August 2014, the deputy Prime Minister Nick Clegg (2014) argued that net migration should be reduced and, in order to do so, 'the way freedom of movement works should change'. In November 2014, following a similar but more Eurosceptic line, David Cameron (2014) criticised New Labour's rhetoric on immigration by saying that immigration was not a universal benefit, nor a necessary consequence of globalisation. Cameron instead made the claim that non-EU net migration had been brought down by a quarter while the government's office of statistics recorded an increase (ONS 2017). ${ }^{20}$ Cameron (2014), however, sought to shift the debate to the large number of EU migrants coming to Britain, saying 'when trust in the EU is already so low, we cannot afford to leave injustices like this to fester.' In a speech to the Conservative Party conference, Theresa May (2015) stated 'The numbers coming from Europe are unsustainable and the rules have to change'. The 2015 party manifesto directly connected the issue of migration to the EU, emphasised the issue of EU migration explicitly as a core concern (an element which was absent in the 2010 Manifesto) and established causality between the government's failure to cut overall annual net migration in the 2010-14 period and more EU migrants coming to the UK for economic reasons (Conservative Party Manifesto, 2015: 29-31, 72-3).

That immigration was the driving force behind the Leave vote in the 2016 EU Referendum is an uncontroversial claim (Goodwin and Milazzo 2017; Portes 2016). In fact, the issue of immigration had become closely linked to the question of EU membership well prior to 2016 (Partos \& Bale 2015:172; Clarke et al. 2017). This has been linked to the growth in popularity of the UK Independence Party (UKIP), which had substantially undermined electoral support for both Conservative and Labour parties, becoming the third largest party by share of the vote in the 2015 General Election and winning its first MP through the politicization of immigration and Britain's membership of the EU (Goodwin and Milazzo 2015; Ford and Goodwin 2014; Partos \& Bale 2015). Moreover, immediately prior to the 2015 election, two Conservative MPs had defected to UKIP. It is in this context of the increasing politicization of both immigration and the EU that David Cameron committed to holding a referendum on Britain's membership of the EU, in the nowinfamous Bloomberg speech in January 2013.

Noteworthy in the literature is a general failure to distinguish between EU migration which the British state was legally unable to manage directly - and non-EU migration - of which the state has always held complete control (see, for example, Bale 2015:180). Recent scholarship on EU immigration and Brexit does note, however, that the British state had the option to place a 
moratorium on free movement from the 2004 accession countries (see for example, Parker 2017; Goodwin \& Milazzo 2017; Thompson 2017:5) but does not seem to consider therefore that the decision not to was a deliberate and strategic one by the British state. Thompson (2017:5) notes that this decision 'weakened the basis of domestic political support for Britain's EU membership' but this does not translate into recognition that the EU was used as a means to depoliticize an immigration policy that had been an intentional aspect of British state management since the mid1990 (for an exception, see Geddes, 2005). It is also significant to note that the depoliticizing effect of shifting the political character of decision-making on to the EU was also a simultaneous politicization of Britain's membership of the EU.

While the Conservative Party won a slim majority in the 2015 General Election, this was won at the cost of politicizing Britain's membership of the EU. The key consequence of this was that the 2016 referendum campaign was fought in a political environment in which immigration, economic conditions and Britain's membership of the European Union were closely linked. Following the success of leave.eu's immigration-focused campaign, the official Leave campaign, 'Vote Leave', switched its own focus to immigration (BBC 2016a). This was highly successful and left the official Remain campaign's focus on the technical, economic benefits of EU membership finding little purchase on the electorate (Cassidy 2016). Indeed, antipathy towards immigration among the British electorate was the strongest indication of opposition to Britain's membership of the EU (Portes 2016:14; Vasilopoulou 2016).

Having realized the economic benefits that can be derived from a more open immigration policy, Coalition and Conservative governments continued such a policy from 2010, despite tough rhetoric on immigration in general and hostile policies. Both governments sought to link immigration policy with EU membership as a means of displacing the political fallout from this strategy. As such, the British state did not try to control or restrict either EU or non-EU migration into the UK categorically but it systematically aspired to impose border-enforcing practices as highlighted by Mezzadra and Nielsen (2012, 2013) to filter 'unwanted' migrants (Geddes 2005: 724) regardless of their origins in line with the needs of capital accumulation. This policy was not forced upon the state by an external entity - despite repeated claims by state managers, echoed by journalists and academics - but the state has sought to blame the EU for a policy direction with a clear political-economic goal.

\section{Conclusion}

This paper has sought to contextualize Britain's decision to exit the European Union in terms of the nature of capitalist society and the contingencies of governing Britain with specific reference to historic and contemporary immigration policy. The paper has drawn attention to three key elements of capitalist society that formed the conditions upon which we must understand Britain's decision to leave the EU: the worker; the sundering of political and economic aspects of social life; and the formal territorialisation of the national state form and its attendant ideology. In situating our paper historically, we have sought to stress the highly contingent nature of current social circumstances. Firstly, capitalism itself is not an ideal type nor a consequence of some inherent 
quality of human nature but a historically constituted form of social production (Marx 1976 [1867]:179). Secondly, while conditioned by capitalist society, the direction of British governing strategy has remained under the control and is a consequence of the choices of key state managers.

British immigration policy has consistently trodden a path between economic benefits and the political consequences of those benefits. As such, immigration policy has tended to be restrictive as British politicians sought to exploit the electoral benefits of this - generally racist approach to immigration. In the immediate post-war period, Britain initially adopted a more open immigration policy to address serious labour shortages, using its status as an imperial power to this end. However, immigration quickly became a highly politicized issue and state managers did not have the governing autonomy to use immigration policy to act in the interests of capital-in-general. Once again, Britain used imperial relationships to further restrict immigration. Clearly other factors were involved in the underperformance of the British economy during the post-war period; however, with the labour supply limited, the British economy, prior to the 1990s, was beset by high wage growth, high inflation and low productivity compared to other G7 countries (ONS 2015). Successive immigration policies can best be understood in terms of Britain's perennial governing problems (Burnham 2001:127).

The central goal of Conservative governing strategy during the 1990s, following the catastrophe of Black Wednesday, was to bring down inflation and maintain it at a relatively low level (Kettell 2004:142). As highlighted by Geddes (2005), one means of achieving this - certainly in the later years of this government - was to increase levels of immigration into Britain in a controlled manner while simultaneously introducing stricter conditions and criteria to admit required skills and labour and limit other migrant groups such as asylum seekers and refugees. Following the election of New Labour in 1997, with net inwards migration levels already rising, the rhetoric of a stricter immigration policy remained intact. However, state managers set about substantially increasing levels of net inward migration and simultaneously institutionalising the points based system targeting non-EU migrants, immigration detention practices targeting asylum seekers and arm's length control of migration related matters through the Migration Advisory Committee as well as cooperating with the EU strategically and selectively on the management of these diverse 'unwanted' migrants (Geddes, 2005). In this sense 'open' immigration policy was never truly open.

The tension between workers can also become a problem for governing authorities. This tension, certainly in the post-war period, initially led the British state to prohibit large-scale migration to the UK - worsening economic conditions - and then to liberalise immigration controls - politicizing economic conditions and the issue of immigration. Recent governments, Labour, Conservative and Coalition, have sought to depoliticise the issue of immigration, invoking either globalization or the European Union. These strategies ultimately failed, contributing to the politicization of Britain's membership of the European Union, the referendum on membership and the vote for Brexit.

A notable conclusion from our approach to British immigration policy is the remarkable continuity and coherence between governments of the different parties on this issue. As such, 
successive British governments' governing strategies can be better understood not in terms of party politics or electoral results but in terms of the constraints placed on state management by global capital. ${ }^{21}$ As Bonefeld et al (1995:198) note,

'The struggle between the Labour Party and the Conservative Party is, to a great extent, a ritual conflict around symbols, which disguises a consensus between the parties on key policy areas. Any party in government is subject to the constraints presented by global financial markets, class struggle and Britain's position in the world market. The means available to government to deal with these constraints are broadly similar'

The politicisation of migration in the immediate post-war period in Britain and politicisation that we are witnessing today share a number of commonalities when it comes to the perpetual governing problems of the British political economy as highlighted earlier and the role of the state in the management of labour and class struggle. However, the scale of the movement of capital across borders and the degree of its confinement within the territorial borders of the nation-state reveal a number of differences shaping the politicisation dynamics between post-1945 and post2010 contexts. Given the relatively high degree of confinement of the capital circuit within the national territorial borders of the state until the late 1970s, politicisation of migration did not fundamentally endanger the accumulation and legitimation dynamics of the capitalist social relations as other governing 'fixes' in the management of labour and class struggle could be found elsewhere in social/welfare policies albeit in blatantly racist form (Bhambra, 2017: 221; Shilliam 2018).

In contrast, post-2010 politicisation of migration occurred in a context of extremely limited territorial control of state managers over capital, constraining the emergence of governing fixes in other policy areas (the resistance against the Corbynist social policy alternatives within the ranks of the British state and governing parties is a case in point). Therefore, one may argue that the durability and legitimacy of post-2010 politicisation dynamics are likely to be far more contested.

The sequence of events leading to Britain's decision to leave the EU offers an account of state managers seeking to avoid the political consequences of their own immigration policy by externalizing responsibility for those consequences. In this view, the question of migration - and the management of labour - for state managers is an unresolvable dilemma rooted in the inherently contradictory nature of capitalist social relations. Future British immigration policy will continue to be made under these conditions but has become highly politicized due to the failure of the depoliticizing move made by Coalition and Conservative politicians. Given the outcome of the referendum, governing autonomy will, with some sense of irony, be severely restricted to use immigration policy to manage labour in the future.

\footnotetext{
${ }^{1}$ Earlier drafts of this paper were presented at the 2017 IPEG Annual Workshop in Liverpool and the $3^{\text {rd }}$ SVOC Conference in Budapest. We would also like to thank Prem Kumar Rajaram, James Brassett, Kate Law, Dan Bulley and
} 
Tamas Gerocs for their insightful comments and feedback on the paper. We would also like to thank both reviewers for their helpful and supportive comments. All errors and omissions are our own.

${ }^{2}$ This point does not suggest that immigration, representing a broad array of motivations, agents and diverse positionalities of migrants, is reducible solely to labour migration. That is to say, not all migration is migration of labourers as such. Certainly, differential access to capital, resources, and means of production exists among migrants which position them in different scales within the hierarchy of both the sending and receiving countries. The focus of this paper is the immigration policy of the British state and its mobilisation in order to manage labour-power under capitalism. We would like to thank one of the anonymous reviewers for raising this point so that we can clarify it here.

${ }^{3}$ This paper focuses on demystifying and exposing the agency of the British state and its strategies in 'tackling' the 'problem' of migrants and migration. However the agency of migrants, 'bearers' of labour power, in challenging this politics of control and manipulation as part of contemporary class struggles and worker resistance are equally central in any comprehensive account of contested politics of migration (Mezzadra and Neilson, 2013: 20; see also Dinerstein, 2002).

${ }^{4}$ See, for example, Burnham (2001; 2014), Copley (2019), Kettell (2004; 2008), Rogers (2009; 2012), Sutton (2017).

${ }^{5}$ Nevertheless it is important to note that Marx acknowledged the role of colonialism in the Americas, Africa and India as part of a global process of primitive accumulation in the advent of capitalism as it emerged at the end of the seventeenth century in England (Marx, [1867] 1990: 915 cited by Anievas and Nisancioglu, 2013: 84).

${ }^{6}$ Wood and Flinders (2014:158) note that 'binding the hands' of politicians on policies such as immigration is one tool of depoliticization.

${ }^{7}$ The problem of British relative decline and the state's ability to manage this phenomenon is a well-debated issue in British political economy. The origins of British decline have been attributed to the end of empire and changes to the global economy (Dorling \& Tomlinson 2019; Tomlinson 1982), the institutional failures of the state (Brittan 1977; Beer 1982), and the cultural particularities of the British economy (Wiener 1981; Elbaum \& Lazonick 1984). This debate has even seen a critique of the notion of decline itself and its use as a narrative for political purposes (Tomlinson 1996; 2016). For an overview of the various narratives of decline see Gamble 1994:3-40; Tomlinson 2014, 2017).

${ }^{8}$ Statistical evidence for the entry of migrants to Britain was not gathered until 1962 (Gordon 1985:14). Estimates for non-white migration in this period are generally based on census data and therefore vary considerably. Gordon (1985:14) estimates, for example, that there were 51,000 non-white migrants in Britain in 1951, growing to 278 , 000 by 1961. Waters (1997:209) estimates that the non-white population was 74,500 in 1951, growing to nearly 500,000 by 1962.

${ }^{9}$ In practice, British immigration policy was racist, encouraging immigration from the so-called 'White Dominions' and seeking to limit non-white immigration, but deliberately sought to avoid appearing racist ( $C A B / 128 / 27$, Conclusions, December 1954). As Spencer (1997:152) notes, 'In the post-war years British governments, both Labour and Conservative, attempted with some success to maintain and expand the restrictive arrangements previously imposed by colonial governments at London's request. They made considerable efforts to find new ways to prevent the movement of Asian and black British subjects to the United Kingdom for settlement and to block loopholes as they appeared.'

${ }^{10}$ Carter et al (1987:2) refer, for example, to informal practices in the Caribbean: 'Governors were asked to tamper with shipping lists and schedules to place migrant workers at the back of the queve; to cordon off ports to prevent passport holding stowaways from boarding ships; and to delay the issue of passports to migrants.' Such measures were routinely used throughout the Commonwealth.

${ }^{11}$ Ironically, this led to a huge surge in non-white immigration from the announcement of the legislation up to the passing of the Bill as immigrants from the Colonies sought to 'beat the ban', moving to Britain while the chance still existed (Spencer 1997:131)

${ }^{12}$ The management of the non-EEC immigration remained under the control of the British state as specifically noted in the General Declaration on Articles 13 to 19 of the Single European Act, effective from 1987.

13 'Annual net migration' measure has been one of the most referenced yet controversial indicators during the EU Referendum as invoked by the state managers and subsequently picked up by the media and became prominent in public debate (Allen, 2016: 9). Scholars have strongly argued against the reliability and accuracy of this data given the inclusion of all citizenships inclusive of British citizens leaving or coming from abroad in the headline net migration figures (Vargas-Silva and Sumption, 2018: 3). Vargas-Silva and Sumption (2018:4) note that 'British citizens are the only group characterised by continuous net emigration since 1991' with peaks occurring in 2004 and 2006 . In addition, the discrepancy between the ONS and Home Office visa issuance data have long been acknowledged to have led to overestimation of non-EU migration overall (Partos, 2018; ONS Statement 2017). Therefore the highly politicised nature of migration debate around inaccurate and contested figures and statistics should be acknowledged with caution here since '[u]sing these data to draw policy conclusions about how to treat different types of migration (for example, to draw up a plan for reducing net migration to a given level), would be misleading' (Vargas-Silva and 
Sumption, 2018: 7; see also Geddes, 2005: 725-6). Even though we also refer to the ONS data throughout our paper, we would like to highlight the above disclaimer in order to focus the debate on the political uses and abuses of these figures which helped state managers and other pro-Brexit actors to propose and legitimise anti-migrant and racist policies.

${ }^{14}$ Geddes (2005: 736) emphasises the implications of EU's restrictive policies in fighting undocumented migration which UK governments enthusiastically adopted since the late 1990s, for refugees and asylum seekers as 'the more difficult it becomes for people to enter an EU member state as a result of tougher controls on border crossings, then the more difficult it will be for them to make an asylum application.'

${ }^{15}$ There is some debate over the predictions of A8 immigration to the UK, which tends to focus on the likelihood of whether Germany would impose restrictions on immigration from A8 countries. This did indeed happen, leading A8 immigration to the UK to be at the higher end of the estimate provided to the Labour government by economist Christian Dustmann (BBC 2013b). Dustmann claimed that A8 immigration to the UK would be around 13,000 but that with German restrictions would be 46,000, which was closer to the real figure of around 50,000 (ibid.). Interestingly, Dustmann et al. (2010:9-13) subsequently argued that, between 2004 and 2008, the average hourly wage of A8 workers was nearly half that of British workers.

${ }^{16}$ MAC is made up of a chair, five independent economists and a Home Office representative and tasked with advising the government on the impact of immigration and the skills shortages in the UK labour market in particular (Migration Advisory Committee).

${ }^{17}$ Whether the media shapes or reflects public opinion on key issues is a contested matter. With this disclaimer, Allen (2016: 15) reports that the newspaper coverage of the issue of immigration (nearly half of articles mentioning a problem connected to either EU or undocumented migration) in the 2006-May 2015 period placed the responsibility and blame with the government in office. Out of over 170,000 articles analysed across 19 national UK publications in this period running up to the EU Referendum, $10 \%$ of the articles placed blame on EU bodies and other European states for problems relating to EU migration (ibid.). In addition, he found that the journalists themselves framed problems in the migration debate rather than solely reporting on others' data and analysis which provided evidence for the media's role in shaping public opinion in this instance (ibid.: 2 ).

${ }^{18}$ Bearing in mind prior cautions on the accuracy of these figures, the ONS recorded net inward migration increasing by 15,000 to 250,000 in 2010 (ONS 2012).

${ }^{19}$ Most notoriously in the later 2018 Windrush Scandal (Guardian, 2018, 2019; House of Lords, 2018)

${ }^{20}$ For 2014, from 150,000 to nearly 200,000 (ONS 2017)

${ }^{21}$ This is not exclusively a Marxist position. This view is held widely in, particularly, European policy making literature. See, for example, Broad \& Daddow (2010:219), Bulpitt (1992:258-259).

\section{Bibliography}

Allen W. L. 2016. Report: A Decade of Immigration in the British Press. The Migration Observatory at the University of Oxford.

Anderson P. 1974. Lineages Of The Absolutist State London:Verso.

Anievas, A. and Nisancioglu, K. (2013.) What's at Stake in the Transition Debate? Rethinking the

Origins of Capitalism and the 'Rise of the West', Millennium: Journal of International Studies, Vol. 42 (1), 78-102.

Apostolova R. 2014. 'The German Greens: Or how they learned to stop worrying and game the 'poverty migrants', LeftEast, http://www.criticatac.ro/lefteast/the-german-greens-or-how-theylearned-to-stop-worrying-and-game-the-poverty-migrants/ (20 ${ }^{\text {th }}$ July 2017)

Apostolova R. 2015. 'Economic vs. political: Violent abstractions in Europe's refugee crisis', FocaalBlog, 10 December. www.focaalblog.com/2015/12/10/raia-apostolova-economic-vspolitical-violent-abstractions-in-europes-refugee-crisis (6th July 2017)

Apostolova R. 2016. 'The Real Appearance of the Economic/Political Binary: Claiming Asylum in Bulgaria', Intersections EEJSP, 24., pp. 33-50. 
Balch A. \& Balabanova E. 2016. Ethics, Politics and Migration: Public Debates on the Free Movement of Romanians and Bulgarians in the UK, 2006-2013. Politics, Vol. 36(1), 19-35.

Bale, T., \& Partos, R. 2014. Why mainstream parties change policy on migration: A UK case studyThe Conservative Party, immigration and asylum, 1960-2010. Comparative European Politics, 12:6, 603-619

Bale, T., Hampshire, J., \& Partos, R. 2011. Having One's Cake and Eating It Too: Cameron's Conservatives and Immigration. The Political Quarterly, 8:23, 398-406

Bale, T. 2008. Turning round the telescope. Centre-right parties and immigration and integration policy in Europe. Journal of European Public Policy, 15:3, 315-330

BBC 2016. EU referendum: Vote Leave focuses on immigration http://www.bbc.co.uk/news/ukpolitics-eu-referendum-36375492 (5th October 2017)

BBC 2013a. Terror suspect Hilal Al-Jedda stripped of UK citizenship, $2^{\text {nd }}$ December 2013 accessed from: https://www.bbc.co.uk/news/uk-25190305 (11th November 2019)

BBC 2013b Prof says his ' 13,000 EU migrants' report 'misinterpreted' https://www.bbc.co.uk/news/uk-politics-21682810 (16th July 2019)

Beer, S. H. (1982). Britain against itself: The political contradictions of collectivism. London: Faber \& Faber.

Benson M. \& Lewis C. 2019. 'Brexit, British People of Colour in the EU-27 and everyday racism in Britain and Europe', Ethnic and Racial Studies, DOI: 10.1080/01419870.2019.1599134

Bhambra G. 2017. 'Brexit, Trump, and 'methodological whiteness': on the misrecognition of race and class'. The British Journal of Sociology. Volume 68 Issue S1, 214-232.

Blair T 2010. A Journey London: Arrow

Blair T 2004. Speech to the Confederation of British Industry, $27^{\text {th }}$ April 2004 , accessed from: https://www.theguardian.com/politics/2004/apr/27/immigrationpolicy.speeches (4th July 2018)

Bloch, A. (2000). A new era or more of the same? Asylum policy in the UK. Journal of refugee studies, 13(1), 29-42.

Boatca M. 2015. Global Inequalities beyond Occidentalism. Surrey, Burlington: Ashgate.

Bonefeld W 2011. Primitive Accumulation And Capitalist Accumulation: Notes On Social Constitution And Expropriation Science \& Society 75:3, 379-399

Bonefeld, W., Brown, A. and Burnham, P., 1995. A Major Crisis: The Politics of Economic Policy in Britain in the 1990s London: Dartmouth Publishing Co.

Brenner R 1976. Agrarian Class Structure And Economic Development In Pre-Industrial Europe Past \& Present 70, 30-75

British Nationality Act. $1948 . \quad$ accessed from https://www.legislation.gov.uk/ukpga/1948/56/pdfs/ukpga_19480056_en.pdf (3rd June 2019).

Brittan, S., 1977. The economic consequences of democracy. Temple Smith.

Broad M \& Daddow O 2010. Half-Remembered Quotations from Mostly Forgotten Speeches: The Limits of Labour's European Policy Discourse The British Journal of Politics and International Relations 12:2 205-222

Brown G 2010. Spitalfields Speech, $31^{\text {st }}$ March 2010, accessed from: 
http://www.telegraph.co.uk/news/uknews/immigration/7541042/General-Election-2010-GordonBrown-warns-against-immigration-scaremongering.html (gth August 2017)

Bulpitt J 1996. 'The European Question', in D Marquand and A Seldon eds. The Ideas That Shaped Post-War Britain London: Fontana, 214-256

Bulpitt J 1992. Conservative Leaders and the 'Euro-Ratchet': Five Doses of Scepticism The Political Quarterly 63:3, 258-275

Burnham P. 2017. Neo-Liberalism, Crisis and the Contradictions Of Depoliticisation Partecipazione e Conflitto, 10: 2, 357-380.

Burnham P 2014. Depoliticisation: Economic Crisis and Political Management Policy \& Politics 42:2 189-206.

Burnham P 2001. New Labour the Politics of Depoliticisation British Journal of Politics and International Relations 3:2 127-149

Cameron D 2011. Immigration Speech, $14^{\text {th }}$ April 2011, accessed from: https://www.bbc.co.uk/news/uk-politics-13083781 (11th July 2019)

Cameron D 2014. EU Immigration Speech, $28^{\text {th }}$ November 2014, accessed from: http://www.bbc.co.uk/news/uk-politics-30250299 (1st September 2017)

Cantat C. 2016. ' Rethinking Mobilities: Solidarity and Migrant Struggles Beyond Narratives of Crisis', Intersections, 2:4, pp. 11-32.

Carter B. Harris C and Joshi S. 1987. 'The 1951-55 Conservative government and the racialization of black immigration', Policy Papers in Ethnic Relations. No: 11. Centre for Research in Ethnic Relations, University of Warwick, from: https://web.warwick.ac.uk/fac/soc/CRER_RC/publications/pdfs/Policy\%2oPapers\%2oin\%2oEthnic \%20Relations/PolicyP\%20No.11.pdf (3rd June 2019).

Cassidy J 2016. Why the Remain Campaign Lost the Brexit Vote The New Yorker, 24 June 2016, accessed from: https://www.newyorker.com/news/john-cassidy/why-the-remain-campaign-lostthe-brexit-vote (5th October 2017)

Clarke H, Goodwin, M \& Whiteley P. 2017. Brexit: Why Britain Voted to Leave the European Union. Cambridge: Cambridge University Press

Clarke S 1988. Keynesianism, Monetarism and the Crisis of the State, Aldershot: Edward Elgar.

Clarke S. 1994. Marx's Theory of Crisis, Basingstoke: Macmillan Press.

Clegg N 2014. Immigration Speech, London, $5^{\text {th }}$ August 2014 accessed from: https://www.libdems.org.uk/nick_clegg_s_immigration_speech (1st September 2017)

Cole P. 2016. 'Global displacement and the topography of theory' Journal of Global Ethics, 12:3, 260-268.

Commonwealth Immigration Act. 1962 accessed from https://www.freemovement.org.uk/wpcontent/uploads/2018/04/CIA1962.pdf (3rd June 2019).

Copley, J., 2019. Why were capital controls abandoned? The case of Britain's abolition of exchange controls, 1977-1979. The British Journal of Politics and International Relations, 21(2), pp.403-420.

De Genova N. 2016. 'Toward a Marxian anthropology? Bare, abstract, mobile, global', Dialect Anthropol, Vol. 40, pp. 125-141. 
De Haas H. 2005. 'International Migration, Remittances and Development: myths and facts' Third World Quarterly. Vol. 26, No. 8, 1269-1284.

De Haas H. 2012. 'The Migration and Development Pendulum: A Critical View on Research and Policy' International Migration. Vol. 50 (3), 8-25.

Denning M 2010. Wageless Life New Left Review 66 pp.79-97

Dennison J. \& Geddes A. 2018. Brexit and the perils of 'Europeanised' migration, Journal of European Public Policy, 25:8, 1137-1153.

Dinerstein A. 2002. Regaining Materiality: Unemployment and the Invisible Subjectivity of Labour, in A. Dinerstein and M. Neary eds.. The Labour Debate: An Investigation into the Theory and Reality of Capitalist Work, Aldershot, Vermont: Ashgate.

Donmez P. 2014a. 'Crisis and Regional Governance Attempts: the Curious Case of Turkey in Critical Perspective", in T. Haastrup and J. Eun eds.., Regionalising Global Crises: The Financial Crisis and New Frontiers in Regional Governance, Palgrave MacMillan International Political Economy Series. Donmez P. 2019. 'Politicisation as governing strategy versus resistance: Demystifying capitalist social relations and state in Turkey' in J. Buller et. al. eds., Comparing Strategies of Depoliticisation in Europe: Governance, Resistance and Anti-politics, Palgrave Macmillan.

Dorling D. and Tomlinson S. 2019. Rule Brittania Brexit and the End of Empire. Biteback Publishing. Dustmann, C., Frattini, T. and Halls, C., 2010. Assessing the Fiscal Costs and Benefits of A8 Migration to the UK. Fiscal Studies, 31(1), pp.1-41.

Dyer C 2002. Making A Living In The Middle Ages: The People Of Britain 850-1520 New Haven: Yale University Press

Elbaum, B., \& Lazonick, W. (1984). The decline of the British economy: An institutional perspective. The Journal of Economic History, 44(2), 567-583.

Fanon F. 2004. [1961] The Wretched of the Earth, New York: Grove Press.

Favell, A. 2019. 'Brexit: a requiem for the post-national society?', Global Discourse, vol 9, no 1, 15768.

Federici S. 2002. 'The Great Caliban: The Struggle Against the Rebel Body', The Commoner, January, http://www.thecommoner.org ( $9^{\text {th }}$ August 2017)

Federici S. 2004. Caliban and the Witch: Women, the Body and Primitive Accumulation, New York: Autonomedia.

Fekete, L. (2001). The emergence of xeno-racism. Race \& Class, 43(2), $23-40$.

Ferguson S. \& McNally D. 2015. Precarious Migrants: Gender, Race and the Social Reproduction of a Global Working Class. Socialist Register, Vol. 51, pp. 1-23.

Financial Times. 2018. 'The effects of EU migration on Britain in 5 charts', accessed from: https://www.ft.com/content/797f7b42-bb44-11e8-94b2-17176fbf93f 5 (6th June 2019)

Flinders M. \& Buller J. 2006. 'Depoliticisation: Principles, Tactics and Tools'. British Politics, 1, 293318.

Ford R \& Somerville W 2010. Immigration and the 2010 General Election: More than meets the eye in Finch $\mathrm{T} \&$ Goodhart $\mathrm{D}$ eds. Immigration Under Labour, accessed from: 
http://www.ippr.org/files/images/media/files/publication/2011/05//mmigration\%2ounder\%2oLab our\%20Nov2010 1812.pdf ( $3{ }^{\text {rd }}$ October 2017)

Ford, R., \& Goodwin, M. J. 2014. Revolt on the right: Explaining support for the radical right in Britain. Routledge.

Gamble A. 2018. Taking back control: the political implications of Brexit, Journal of European Public Policy, 25:8, 1215-1232.

Gamble, A., 1994. Britain in decline: economic policy, political strategy and the British state. Basingstoke: Macmillan Press.

Geddes A. 2014. The EU, UKIP and the Politics of Immigration in Britain. The Political Quarterly, Vol. 85 , No. 3, pp. 289-295.

Geddes A. 2005. Getting the best of both worlds? Britain, the EU and migration policy. International Affairs, 81, 4, 723-740.

Geddes A. and Scholten P. 2016. The politics of migration and immigration in Europe. Los Angeles, London: Sage.

Giddings P \& Drewry G eds. 2004. Britain In The European Union: Law, Policy And Parliament Basingstoke: Palgrave

Goodwin, M., \& Milazzo, C 2017. Taking back control? Investigating the role of immigration in the 2016 vote for Brexit The British Journal of Politics and International Relations 19:3, 450-464.

Goodwin, M., \& Milazzo, C. 2015.. UKIP: Inside the campaign to redraw the map of British politics. Oxford: Oxford University Press.

Gordon, P., 1985. Policing immigration: Britain's internal controls. Pluto Press

Guardian 2012. Supreme court strikes down Home Office's back-door changes to immigration rules, $18^{\text {th }}$ July 2012 accessed from: https://www.theguardian.com/law/2012/jul/18/supreme-courtimmigration-rules (11th November 2019)Guardian 2013. Jack Straw: Labour made mistake letting Poles in early, 13 November 2013 accessed from: https://www.theguardian.com/politics/2013/nov/13/jack-straw-labour-mistake-poles (9th August 2017)

Guardian 2018. How the hostile environment crept into UK schools, hospitals and homes, 1 August 2018 accessed from: https://www.theguardian.com/uk-news/2018/aug/01/hostile-environmentimmigrants-crept-into-schools-hospitals-homes-border-guards (13th June 2019)

Guardian 2019. British children in poverty denied basic benefits by Home Office, report finds, 13 June 2019 accessed from: https://www.theguardian.com/uk-news/2019/jun/13/no-recourse-publicfund-damning-immigration-report-criticises-home-office-child-poverty (13th June 2019)

Guardian 2001. The Abridged Labour Manifesto, $16^{\text {th }}$ May 2001, accessed from: https://www.theguardian.com/politics/2001/may/16/election2001.uk5 (11th July 2019)

Hansen R 2000. Citizenship and immigration in postwar Britain Oxford: Oxford University Press Harvey C J 1999. Immigration And Asylum Law: New Covenants And Familiar Challenges Public Law $23-34$

Harvey, D. 1982.. The Limits To Capital London:Blackwell 
Hay, C. 2009.. Good inflation, bad inflation: The housing boom, economic growth and the disaggregation of inflationary preferences in the UK and Ireland. The British Journal of Politics \& International Relations, 11:3, 461-478

Hilton R 1992. Introduction in Sweezy P M \& Hilton R eds. 1992. The Transition From Feudalism To Capitalism Verso: London

Hilton R 1990. Class Conflict And The Crisis Of Feudalism: Essays In Medieval Social History Revised Edition. Verso: London

Holloway J. and Picciotto S. 1991. 'Capital, Crisis and the State', in The State Debate, ed. S. Clarke, London: Macmillan.

Home Office 2019. Policy and legislative changes affecting migration to the UK: timeline, Guidance. accessed from: https://www.gov.uk/government/publications/policy-and-legislative-changesaffecting-migration-to-the-uk-timeline (8th November 2019)

Home Office 2001. RDS Occasional Paper 67-Migration: An Economic and Social Analysis London: HMSO

Home Office 1998. Fairer, Faster, Firmer: A Modern Approach to Immigration and Asylum London: HMSO

House of Lords 2018. Impact of 'Hostile Environment' Policy Debate on 14 June 2018, Library Briefing, 11 June 2018, from: https://researchbriefings.files.parliament.uk/documents/LLN-2018-0064/LLN-2018-0064.pdf (13th June 2019)

Ipsos MORI 2006. Issues Index: 1997-2006. Accessed from: https://www.ipsos.com/ipsos-mori/enuk/issues-index-1997-2006 (10 June 2019)

Ipsos MORI 2014 Issue Index: 2007 onwards. Accessed from: https://www.ipsos.com/ipsosmori/en-uk/issues-index-2007-onwards (10th June 2019)

James W 2004. The Black Experience In Twentieth-Century Britain, in Morgan P D \& Hawkins S eds. Black Experience and the Empire Oxford: Oxford University Press, pp.347-386

Kettell S 2004. The Political Economy of Exchange Rate Policy-Making Basingstoke: Palgrave Kettell S 2008. Does Depoliticisation Work? Evidence from Britain's Membership of the Exchange Rate Mechanism 1990 - 1992 British Journal of Politics and International Relations 10:4

Layton-Henry Z 1992. The Politics of Immigration Oxford: Blackwell

LeBaron G. \& Phillips N. 2019. 'States and the Political Economy of Unfree Labour', New Political Economy, 24:1, 1-21.

Lebowitz, M. A. 2003.. Beyond Capital? Palgrave Macmillan UK.

Le De L. Gaillard J. C. Friesen W. Pupualii M. Brown C. \& Aupito A. 2016 'Our family comes first: migrants' perspectives on remittances in disaster'. Migration and Development. 5:1, 130-148

Luxemburg R 2003 [1913]. The Accumulation Of Capital Routledge: London

Mandelson P 2010. The Third Man. London: Harper

Marx, K. 1971 [1859]. Contribution to the Critique of Political Economy. London: Lawrence and Wishart. 
Marx K \& Engels F 1975 [1844]. Economic and Philosophic Manuscripts Collected Works Vol. 3. London: Lawrence and Wishart

Marx K 1993 [1858] Grundrisse London: Penguin

Marx K. 1976 [1847] Wages Collected Works Vol. 6. London: Lawrence and Wishart

Marx K 1996 [1867]. Capital Volume I Collected Works Vol. 35. London: Lawrence and Wishart

Marx K 2010 [1894]. Capital Volume III Collected Works Vol. 37. London: Lawrence and Wishart

Marx K \& Engels F 1988 [1870]. Letters 1868 - 1870 Collected Works Vol.43. London: Lawrence and Wishart

May T 2015. Conservative Party Conference speech, $6^{\text {th }}$ October 2015, accessed from: https://www.independent.co.uk/news/uk/politics/theresa-may-s-speech-to-the-conservative-

party-conference-in-full-a6681901.html

May T 2012. An immigration system that works in the national interest, $12^{\text {th }}$ December 2012, accessed from: https://www.gov.uk/government/speeches/home-secretary-speech-on-animmigration-system-that-works-in-the-national-interest (11th July 2019)

Merrill H. 2011. 'Migration and Surplus Populations: Race and Deindustrialization in Northern Italy', Antipode, 43:5, pp 1542-1572.

Messina, A. 2001. The Impacts of Post-WWII Migration to Britain: Policy Constraints, Political Opportunism and the Alteration of Representational Politics. The Review of Politics, 63(2), 259-285. Mezzadra S. and Neilson B. 2013. Border as Method, or, the Multiplication of Labor, Durham: Duke University Press.

Mezzadra S. and Neilson B. 2012. 'Between Inclusion and Exclusion: On the Topology of Global Space and Borders', Theory, Culture \& Society, 294:5, pp. 58-75

Migration Advisory Committee. n. d. About us, accessed from https://www.gov.uk/government/organisations/migration-advisory-committee/about (6th June 2019)

Miles R 1986. Labour Migration, Racism And Capital Accumulation In Western Europe Since 1945: An Overview Capital \& Class 10:1 pp.49-86

Moore M. and Ramsay G. 2017. UK media coverage of the 2016 EU Referendum campaign Centre for the Study of Media, Communication and Power, King's College London.

National Archives

$\mathrm{CAB} / 128 / 27$

Office for National Statistics 2017. Migration Statistics Quarterly Report: May 2017 London: HMSO Office for National Statistics 2014. Migration Statistics Quarterly Report: March 2014 London: HMSO

Office for National Statistics 2012. Migration Statistics Quarterly Report: February 2012 London: HMSO

Office for National Statistics 2017. Statement on net migration and student migration. 25 August. Accessed from:

https://www.ons.gov.uk/news/statementsandletters/statementonnetmigrationandstudentmigrat ion (12 June 2019) 
Parker, O. 2017.. Critical political economy, free movement and Brexit: Beyond the progressive's dilemma. The British Journal of Politics and International Relations 19:3, 479-496.

Partos, R., \& Bale, T. 2015.. Immigration and asylum policy under Cameron's Conservatives. British Politics, 10:2, 169-184

Picciotto S. 1991. 'The Internationalisation of Capital and the International State System', in The State Debate, ed. S. Clarke, London: Macmillan.

Portes, J. 2016. Immigration, free movement and the EU referendum. National Institute Economic Review, 236:1, 14-22.

Portes J. 2018. 'Misunderestimating migration' accessed from: https://ukandeu.ac.uk/misunderestimating-migration/ (6th June 2019)

Portes J. 2019. 'Brexit, immigration and the labour force', accessed from https://ukandeu.ac.uk/brexit-immigration-and-the-labour-force/ (6th June 2019)

Postan MM 1975. The Medieval Economy and Society: An Economic History of Britain in the Middle Ages Middlesex: Penguin

Pradella, L. and Cillo, R., 2015. Immigrant labour in Europe in times of crisis and austerity: An international political economy analysis. Competition \& Change, 19:2, pp.145-16o.

Pröbsting M. 2015. Migration and Super-exploitation: Marxist Theory and the Role of Migration in the present Period of Capitalist Decay. Critique, 43:3-4, 329-346.

Rajaram P. K. 2016. 'Europe's 'Hungarian solution", Radical Philosophy, 197, 2-7.

Rajaram P. K. 2018. 'Refugees as Surplus Population: Race, Migration and Capitalist Value Regimes', New Political Economy, 23:5, 627-639.

Roche, B (2000) UK Migration in a Global Economy Institute for Public Policy Research, 11 September 2000. Accessed from: http://www.jobuk.narod.ru/11_september_20001.html (8th July 2019)

Rogers C 2012. The IMF and European economies: Crisis and conditionality. Basingstoke: Palgrave Macmillan

Rogers C 2009. From Social Contract to 'Social Contrick': The Depoliticisation of Economic PolicyMaking under Harold Wilson, 1974-75 The British Journal of Politics \& International Relations 11:4 $634-651$

Roos, C. 2018. The (De-)Politicization Of EU Freedom Of Movement: Political Parties, Opportunities, And Policy Framing In Germany And The UK. Comparative European Politics, 1-20 Roth K. H. 2010. 'Global Crisis-Global Proletarianization-Counter Perspectives' in Crisis in the Global Eonomy: Financial Markets, Social Struggles, And New Political Scenarios eds.. A. Fumagalli and S. Mezzadra, Los Angeles: Semiotexte..

Shilliam, R., 2018. Race and the undeserving poor: From abolition to Brexit. Agenda Publishing.

Silverman S. J. 2012. "'Regrettable but Necessary?" A Historical and Theoretical Study of the Rise of the U.K. Immigration Detention Estate and Its Opposition' Politics \& Policy, Volume 40, No. 6 : 1131-1157.

Single European Act 1986. accessed from: 
http://www.consilium.europa.eu/vedocs/cmsUpload/SingleEuropeanAct_Crest.pdf (7th March 2018)

Small, S. and Solomos, J., 2006. Race, immigration and politics in Britain: Changing policy agendas and conceptual paradigms 1940s-2000s. International Journal of Comparative Sociology, 47(3-4), pp. $235-257$.

Somerville, W., 2007. Immigration Under New Labour. Policy Press.

Spencer I R 1997. British Immigration Policy Since 1939 Taylor and Francis: London

Spencer I R 1996. The Open Door, Labour Needs And British Immigration Policy, 194555 Immigrants \& Minorities 15:1, 22-41

Squire, V. (2005). 'Integration with diversity in modern Britain': New Labour on nationality, immigration and asylum. Journal of Political Ideologies, 10(1), 51-74.

Sutton, A., 2017. Depoliticisation and the politics of imperialism. British Politics, 12(2), pp.209-230. Sweezy P 1992. A Critique, in Sweezy P M \& Hilton R eds. 1992. The Transition From Feudalism To Capitalism Verso: London

Sweezy P M \& Hilton R eds. 1992. The Transition From Feudalism To Capitalism Verso: London

The Conservative Manifesto. 2010. Invitation to join the government of Britain. Accessed from: https://www.conservatives.com/ /media/Files/Manifesto2010 (10th June 2019)

The Conservative Party Manifesto. 2015. Strong leadership, a clear economic plan, a brighter, more secure future. Accessed from: https://www.conservatives.com/manifesto2015 (10th June 2019)

Thompson H 2017. Inevitability And Contingency: The Political Economy Of Brexit The British Journal of Politics and International Relations 19:3, 434-449

Tomlinson, B.R., 1982. The contraction of England: national decline and the loss of empire. The Journal of Imperial and Commonwealth History, 11(1), pp.58-72.

Tomlinson J (2017) Managing the Economy, Managing the People: Narratives of Economic Life in Britain from Beveridge to Brexit. Oxford: Oxford University Press

Tomlinson, J. (2016). De-industrialization not decline: a new meta-narrative for post-war British history. Twentieth Century British History, 27(1), 76-99.

Tomlinson, J. (2014). The politics of decline: Understanding postwar Britain. Routledge.

Tomlinson, J. 2003. The Decline Of The Empire and the Economic 'Decline' of Britain. Twentieth Century British History, 14:3, 201-221.

Tomlinson, J. (1996). Inventing'decline': the falling behind of the British economy in the postwar years. Economic History Review, 731-757.

Van der Brug, W., D'Amato, G., Berkhout, J. and Ruedin, D., (eds) 2015. The politicisation of migration. Routledge.

van der Linden M. 2001. 'Global Labor History and the Modern World- System: Thoughts at the Twenty-Fifth Anniversary of the Fernand Braudel Center', International Review of Social History, 46, 423-459.

van der Linden M. 2004. 'The "Globalization" of Labor and Working-Class History and its Consequences', International Labor and Working-Class History, 65, 136-156. 
van der Linden M. 2012. 'The Promise and Challenges of Global Labor History', International Labor and Working-Class History, 82, 57-76.

Vargas- Silva C. \& Sumption M. 2018. Briefing: Net Migration in the UK. The Migration Observatory at the University of Oxford

Vasilopoulou, S. 2016. UK Euroscepticism and the Brexit Referendum. The Political Quarterly 87, 219-227

Warner, S. (2019). The 'majesty of the law': depoliticisation, the Rule of Law and judicial independence. British Politics, 1-22.

Watson M \& Hay C 2003. The Discourse Of Globalisation And The Logic Of No Alternative: Rendering The Contingent Necessary In The Political Economy Of New Labour Policy \& Politics 31:3, 289-305

Waters, C., 1997. "Dark strangers" in our midst: discourses of race and nation in Britain, 19471963. Journal of British Studies, 36(2), pp.207-238.

Wiener, M. J. (2004). English culture and the decline of the industrial spirit, 1850-1980. Cambridge University Press.

Wilson D 2017. Marx on Immigration Monthly Review 68:9

Wood, M. and Flinders, M. (2014) Rethinking depoliticisation: Beyond the Governmental. Policy \& Politics 42(2): 151-170.

Wright, C. F. 2012. Immigration Policy And Market Institutions In Liberal Market Economies. Industrial Relations Journal, 43:2, 110-136

Wright C 2010. The Regulation Of European Labour Mobility: National Policy Responses To The Free Movement Of Labour Transition Arrangements Of Recent EU Enlargements SEER Journal for Labour and Social Affairs in Eastern Europe 13:2, 157-179. 